\title{
The Theatre of Drottninghom - Then and Now: Performance between the 18th and 21st centuries
}

StockHolm: StockHolm UNIVERSITY, 2014, xV+296 PAGES

One of the most endearing things about this book is the extent to which it comes across as a conversation between two eminent scholars of the theatre on a topic that they evidently both hold dear and find endlessly fascinating: the Drottningholm Court Theatre. Indeed, the chapters are almost alternated between them and we are privy to their individual (and sometimes contrasting) reactions to the same theatrical events. Topics covered include the 'rediscovery' of the theatre in the 1920s; it's historical, social and theatrical context with reference to Swedish court life, 'baroque' theatre and stage design, and eighteenth-century acting; as well as an appraisal of some significant performances across the ages. The volume is beautifully illustrated with reproductions of contemporary engravings and paintings, photographs of the theatre and its setting, and of twentieth- and twenty-first century productions.

Much of the argument is set within the context of a discussion of 'authenticity'. What makes the theatre special is the fact that it is a well-preserved eighteenth-century theatre with machinery and scenery intact and this is what audiences pay to see - Wiles even describes it at one point as a 'box of tricks' (p. 54). However, in the view of the authors, this setting necessitates certain staging conventions and a style of acting for which today's professional performers have little sympathy or aptitude (not venturing upstage so as to preserve the perspective, not turning one's back on the audience or indulging in inappropriate histrionics). Consequently, their estimation of the relative success of the productions they analyse is framed almost exclusively in terms of the honouring (or not) of such conventions. Apparently they are not alonewhen a director attempted to subvert expectations by having the actors perform against bare flats, the audience felt cheated. But any production at Drottningholm must, by its very nature, be inauthentic, since, however much the director might aim at 'reproduction' or 'reconstruction', it can only ever be a pale imitation of an eighteenth-century exemplar. In Wiles's view, therefore, 'the ultimate challenge at Drottningholm must be to create, somehow, authentic inauthenticity' (p. 57).

The solution proposed is that of the 'historically informed' performance, hence the extensive discussion of eighteenth-century architecture and acting. It is these aspects of the book, however, that I find most problematic. For example, the term 'baroque' is used throughout with, for the most part, insufficient explanation, and it is set in opposition to the 'classical' in a way that is decidedly old-fashioned for a twenty-first century historian of French theatre. Thus, it is asserted that "[a] limitation of the term 'baroque' is its inability to deal with the Italy/France divide critical to the performance of eighteenth-century opera" (p. 133), and reference is also made to the works of Racine sitting uncomfortably within a baroque aesthetic, whereas spectacular quasi 'operatic' productions were, in fact, regularly performed in repertory alongside the masterworks of the 'classical' tradition. Similarly, to my mind, the discussion of the concepts of 'historicity' and 'historicism', which are key to the debate, are confusing rather than elucidating. 
The point that Drottningholm is a 'French' theatre that looks back nostalgically to the age of Louis XIV is well made. I did, however, feel that there was a certain degree of simplification in the discussion of its architectural features and their French antecedents, particularly with regard to the positioning of the royal spectators. The same can also be said of the presentation of the French King's political project. Thus, Louis is described as 'feminising' and 'demilitarising' the nobility by means of fashion and court entertainments in an argument that owes much to Rossellini's Prise de pouvoir de Louis XIV, thereby neglecting the fact that these same members of the noblesse d'épée, with all their powder and perfumes, rushed to offer their lives on the battlefields of Europe.

Comparisons with other (more or less) historic theatres abound and are fruitful, and I particularly liked the discussion of the site's place as a visitor attraction within the heritage industry. The references to the reconstructed Globe and Mark Rylance's comments on the acting style imposed by that auditorium were also very revealing. I did, though, regret that there was no mention of the Sam Wanamaker Playhouse and its use of candlelight, no doubt because publication came too shortly after the opening of that auditorium in January 2014.

In the two authors' collaborative final chapter, "Towards the Future", they discuss (using Pierre Nora's terminology) the theatre's evolution from a milieu de mémoire, where the past and contemporary innovation were brought together, into a lieu de mémoire, "a material, functional and symbolic site established explicitly in order that the past may be remembered". Paradoxically, though, they see in this a way forward, since "[a]s a site of memory, we may find that the theatre becomes something more than an inert container within which we perform, watch and conduct historical experiments. The theatre rather than ourselves may finally become the performer." (p. 212). And they conclude with the incontrovertible statement that "the Drottningholm Court Theatre remains a challenge for future generations of creative artists, reflective historians and responsive audiences" (p. 227). Long may it so continue!

Jan Clarke, Durham University 
